\title{
Book Review-Buchbesprechung-Livre nouveau
}

Peptide Transport in Bacteria and Mammalian Gut. A Ciba Foundation Symposium. Elsevier/Excerpta medica/North-Holland, Amsterdam/London/New York 1972.

180pp.;E2.40/US\$6.25.

This well-made book contains papers and lively discussions of the symposium on peptide transport in bacteria and mammalian gut, held at the Ciba Foundation, London, November 1971. The contributors, bacterial und gut 'transport workers', are the best experts in this field which in the last years has attracted many physiologists not only because of its nutritional importance. After an introduction on nutritional and metabolic aspects of peptide transport (Crampton), peptide transport in bacteria is discussed (Gilvarg) supporting the idea of an oligopeptide carrier operating for peptide transport. Payne presents evidence by different experimental procedures that E. coli possesses separate active transport systems for dipeptides and for oligopeptides. The action of enzymes in E. coli catalysing CO-NH bonds (dipeptidases, aminopeptidases, and endopeptidases) is disdussed by Simmonds. The book's main emphasis, however, is on peptide transport by the mammalian gut (Smyth).

The contributions on rates of peptide uptake by the small intestine (Matthews) and peptides in genetic errors of amino acid transport (Milne) very strongly suggest the presence of specific dipeptide transport carriers operating in the small intestine, whereas Ugolev favours a mechanism of peptide uptake consisting of membrane digestion of dipeptides and subsequent amino acid translocation across the brush border membrane. The mechanism of uptake remains at least quantitatively controversal. The lively discussions of the papers well supplemented with references make the reader of this book feeling a participant of this excellent symposium. This book ist highly recommended to transport physiologists, nutritionalists, gastroenterologists, and pharmacologists. Congratulations to the publisher for the speedy editing of this book. W. Caspary, Göttingen 